\title{
On Language, Culture and Diversity in Spain
}

\author{
Ariadne de Villa \\ Texas Lutheran University, Seguin, Texas, USA
}

\begin{abstract}
The Iberian Peninsula was first inhabited by Celts, Iberians, Carthaginians, Romans, Visigoths, and later Berbers. How is it possible that in a spam of only 50 years, the Berbers were able to go pass the Pyrenees and practically ruled what today is Portugal, Spain, and the region of France? This article attempts to uncover the sociological aspects that helped the Berbers and Arabs govern the Iberian Peninsula. It was due to the commonalities and not the differences that Spain's political leaders went from Arian Visigoths to Muslims for the next 800 years. Ignacio Olague's book La Revolución Islámica en Occidente (The Islamic Revolution in the West), also translated as Les Arabes N'ont Jamais Envahi l'Espagne (The Arabs Never Invaded Spain), serves as one instrument to shed light to how this historical event took place. The result of this fusion of cultures not only created a rich civilization that would plant the seeds of the Renaissance three centuries before it started in Italy, but also contributed to the formation of a new language (between 720-750 AD), El castellano o español (Spanish language), which today is the official language in twenty one countries.

Keywords: multiculturalism, diversity, medieval Spain, Visigoths and Muslims in the Iberian Peninsula, convivencia, contributions of Islamic Spain in the West
\end{abstract}

\section{Introduction}

According to how History is taught in most textbooks in Latin America and Spain, the Moors invaded the Iberian Peninsula in $711 \mathrm{AD}$, which is also known as the Reconquista. The term Reconquista is used to refer from the time of the Visigoths who were Arian Christians (though not Trinitarian Christians, but Unitarian). In order to understand this, it is important to provide a background of the inhabitants of Hispania at the time. The Iberian Peninsula was then populated by Celts, Iberians, Sephardic Jews, Romans, and Visigoths. The majority of the population were Visigoths who as Unitarian Christians believed in one God and were awaiting the coming the Messiah, Jesus. The Visigoths were the politicians in Hispania at the time when the Arabs arrived. The Visigoth rulers were constantly fighting by using force, as a means to control the citizens of the peninsula, which occasioned incessant instability.

Professor and historian De la Guardia (2006) stated that "In no way were the newcomers all Arabs". "The leaders came from Damascus, but they were only a few, and the majority that arrived in Hispania were Muslim Berbers" (De la Guardia, 2006). Dr. Francisco Layna (2006), author and professor of Harvard University, also indicated that "anybody that studies History at a university is aware that the Arab invasion in 711 A.D. never really took place as such" (De La Guardia, 2006). Furthermore, he stated that "the Gibraltar Canal that separates Morocco from Spain has always been known as a tool for merchants that trade on both the Spanish

Ariadne de Villa, assistant professor of Spanish, Ph.D., Department of World Languages and Cultures, Texas Lutheran University, Seguin, Texas, USA. 
and Moroccan Coast. Thus, this was not the first time that the Berbers had visited Spain" (Layna, 2006).

If the previous statement were true, then it could be questioned if the Arabs were in the condition to invade Spain in 711 AD. In the VIII Century, the Berbers in Northern Africa had stopped twice the attempt by the Arabs to conquer it. It would still take 50 years for this civilization to settle in Northern Africa. Hence, the Arabs that came to Northern Africa were weak and only a few in number and therefore could never have invaded Hispania.

Olagüe (2004) added that generally people do not usually reflect on how the "invaders" of North Africa crossed the Gibraltar Canal in a blink of an eye. In other words, how would they be able to conquer 544,192 $\mathrm{km}^{2}$ in the most mountainous region in Europe in a spam of three years? Even more astonishing is how 7,000 men of General Tariq, were enough in number, to defeat Rodrigo and his people in the battle of Guadalete. Olagüe added that "if our math is right, each of the 25,000 Arabs was responsible for $23 \mathrm{~km}^{2}$. Since this was too easy for them, they ran to traverse the Pyrenees to dominate France" (p. 35). An Arab would have never been able to cover $23 \mathrm{~km}^{2}$ and especially in those harsh and mountainous conditions. Olagüe writes that "even if these soldiers conquered Hispania in these conditions, they would have each had $23 \mathrm{~km}^{2}$ of land and therefore would be like a needle in a haystack, compared to the other populations" (Olagüe, 2004, p. 36). For these reasons, we can conclude that an Arab invasion never took place as such. Furthermore, if natives of the Iberian Peninsula would have resented these newcomers, Hispania would have never been Muslim, would have never planted the seeds for the Renaissance in Spain centuries before Italy, and would have not had such scientific and artistic advancements in history that later influenced Europe and the American Continent. If it would have been an invasion, the natives would have forced them to leave Hispania as it occurred when Napoleon in 1808 A.C. tried to seize Spain when he asked permission of the Catholic Spanish Monarchy for his French troop, to pass through Spain in order to invade Portugal. However, once in Spanish territory, Napoleon declared himself Emperor of Spain. It was at this point that the Spanish population resisted and with the help of sticks and stones drove the French troops out of the country. This was never the case when the Muslims arrived in Spain. In contrast, the natives from the Iberian Peninsula welcomed them and were happy to see someone that respected their faith and their traditions and had similar beliefs as the majority of the natives of Hispania were Unitarian Christians. They both believed in only one God, saw Jesus as a messiah, and awaited him.

A proof that all of this took place is the actual Treaty of Tudmir in which is described:

In the name of God, the Merciful and Compassionate. This is a document [granted] by 'Abd al-'Aziz ibn Musá ibn Nusair to Tudmir, son of Ghabdush, establishing a treaty of peace and the promise and protection of God and his Prophet (may God bless him and grant him peace). We ['Abd al-'Aziz] will not set special conditions for him or for any among his men, nor harass him, nor remove him from power. His followers will not be killed or taken prisoner, nor will they be separated from their women and children. They will not be coerced in matters of religion, their churches will not be burned, nor will sacred objects be taken from the realm, [so long as] he [Tudmir] remains sincere and fulfills the [following] conditions that we have set for him. He has reached a settlement concerning seven towns: Orihuela, Valentilla, Alicante, Mula, Bigastro, Ello, and Lorca. He will not give shelter to fugitives, nor to our enemies, nor encourage any protected person to fear us, nor conceal news of our enemies. He and [each of] his men shall [also] pay one dinar every year, together with four measures of wheat, four measures of barley, four liquid measures of concentrated fruit juice, four liquid measures of vinegar, four of honey, and four of olive oil. Slaves must each pay half of this amount. Names of four witnesses follow, and the document is dated from the Muslim month of Rajab, in the year 94 of the Hijra. (Treaty of Tudmir of Orihuela, Spain, $713 \mathrm{CE}$ )

The capitulation agreement between the Arab commander 'Abd'al-'Aziz (son and successor of Musa ibn 
Nusayr) and Theodomir, the Visigothic prince of Murcia, on the surrender of the city of Orihuela, has survived to this date. This agreement was executed in 713 C.E., within two years of the first organized entry of Muslims into Spain from the south, by Commander Tariq ibn Ziyad. The earlier capitulation agreements dating from 711 were essentially the same, but unfortunately are inexistent. The inhabitants of the conquered territories of Spain were suitably impressed by the tolerance which the Muslims offered them once active resistance had ceased. It is these earlier agreements and their successful implementation in the conquered territories that prompted Theodomir and the population of Orihuela to agree to surrender to the Muslims (Al-Allaf, pp. 120-121).

We may still have the question left: If the people that arrived were not Arabs in majority, why are they referred to as Arabs in Spain and why was Arabic spoken and even carved into some of their architectural beauties, such as the Al-hambra, in Granada? Guardia stated that "they were not Arabs, even when the majority of Spain was Muslim. However, they adopted Arabic as their language" (De la Guardia, 2006). Arabic was the language of scholars and Latin was the language of soldiers. The natives of the Iberian Peninsula slowly adapted Arabic as their own language, even people from other faiths. In the IX century, a Bishop of Cordoba wrote the following: "Many of my colleagues read poems and stories; they studied their philosophies in Arabic, not to refute them, but to learn how to express themselves in Arabic more correctly and elegantly" (Álvarez \& Pecharromán, 1998). Olagüe highlighted that it took 300 years for the natives of the Iberian Peninsula to adapt and utilize the Arabic language. An evident fusion of these cultures is portrayed in the jarchas. These were love poems that were written in Arabic and ended in Latin.

Today, 30 percent of the Spanish language that is used in our modern times, according to some linguists, is Arabic. There are some commonly used words that are taught in every Spanish class that directly come from Arabic, such as Ojalá, meaning God-willing or hopefully that originally came from the Islamic expression insha'Allah (God-willing). The personal pronoun usted which is the formal form to address someone with respect also comes from the Arabic word ustadah, meaning master, teacher, or professor. Other proper nouns that also come from Arabic are the following:

Bambalunah (Pamplona), Belad Ulid (Valladolid), Qadis (Cádiz), Malaka (Málaga), Antaquira (Antequera), Lixbuna (Lisboa), Tulaytulah (Toledo), Sarakosta (Zaragoza), Jazirat Shuvr (Alcira), Alcoyil (Alcoy), Al-Akant (Alicante), Al-Basit (Albacete), Al-Qantara (Alcantara), Al-Qa'lah an Nahr (Alcalá de Henares), Gharnatah (Granada) y Al-Jazirah al-Khadra (Algeciras). Asimismo, los siguientes nombres de lugares pueden ser contados en esta herencia cultural: Jabuira (Evora), Corduba (Córduba), Batalyaws (Badajoz), Almunecar, Al-Mariyah (Almeria), Wadi-Ash (Guadix), Jayyan (Jaén), Salmanica (Salamanca), Majrit (Madrid), Abula (Ávila), Wadi al-Hijarah (Guadalajara), Al-Manza (Almansa), Kalat Ayub (Calatayud), Jerunda (Gerona), Lareda (Lérida), Dyaca (Jaca), Al Kacerwes (Cáceres), among many other. (Handal, 2012, pp. 3-4)

The following text in the Spanish language is an ordinary text that any Spanish-speaker would use:

El alfarero alquilaba un bazar en Guadalajara, un almacén azul cerca de la aduana y del alcalde, con una alacena para el arroz, el aceite, las aceitunas, alforjas de garbanzos, los alfajores, un fardo de limones y naranjas, los caramelos, arrobas de azúcar y quintales de café. En un rincón, junto al almanaque, la alfombra y el tambor, se dibujaba la azucena, el alhelí y los lozanos jazmines.

El alguacil de la aldea, un alférez, golpeó adrede a un fulano en la mazmorra porque el haragán robó los candiles, las aquilatadas alhajas y los zafiros del sofá del almirante y del anaquel taraceado de marfil. Ojalá le quiten el dinero.

El alfeñique y el albañil se carcajeaban mezquinamente hasta jadear, y en jerga, de los zaguanes del arrabal por sus adobes carmesí baratos. El zutano zapateaba en la azotea sobando su jarro de alcohol. (Handal, 2012, pp. 2-3) 
Ninety-five of the nouns, verbs, adverbs, and adjectives come from the Arabic language. Moreover, the pronunciation of the consonants " $\mathrm{j}$ " and " $\mathrm{z}$ " is a product of the Arabic language as well. Poetry and language are not the only one example of the advances of Muslim Spain. When in Paris, people would walk on streets of mud; people in Hispania walked on pavement, drainage, and sewage system, and also had plenty of libraries. The Chinese were the ones who invented paper, but it was the Arabs who brought it to Spain and made it possible to print all the knowledge that exited in natural and social sciences. It was this contribution of the Arabs that made it possible to depict this knowledge on paper, and therefore it was possible to create archives in order to store it (libraries). The first university in Europe and the Americas was also founded in Spain, more specifically in Cordoba.

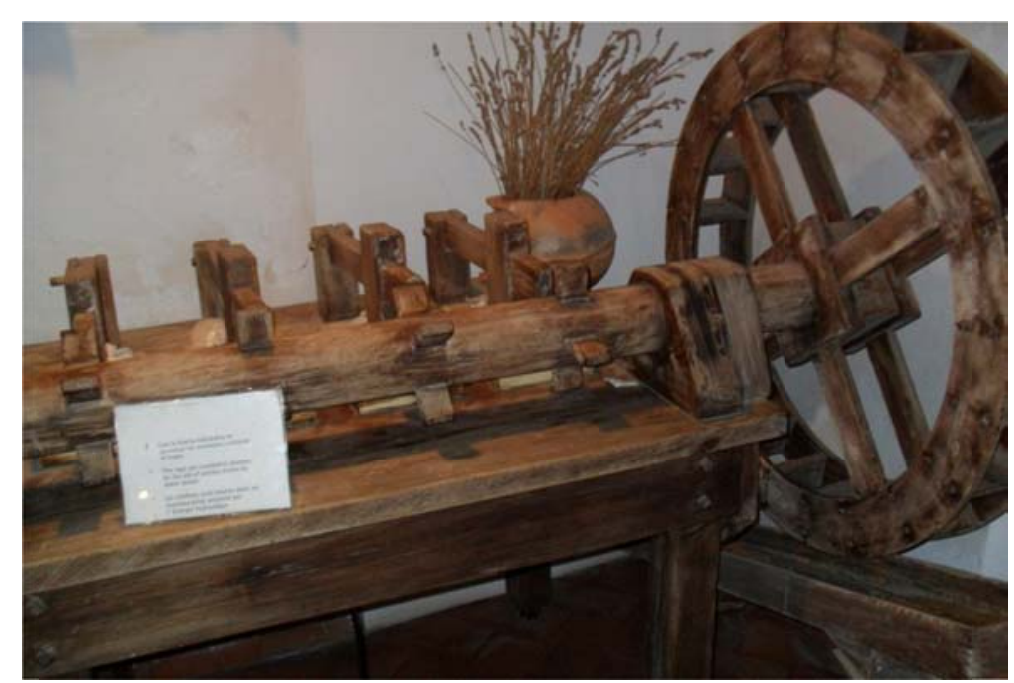

Figure 1. Picture of a paper printer in the Museum of Paper in Cordoba Spain (photographed by Ariadne de Villa). 


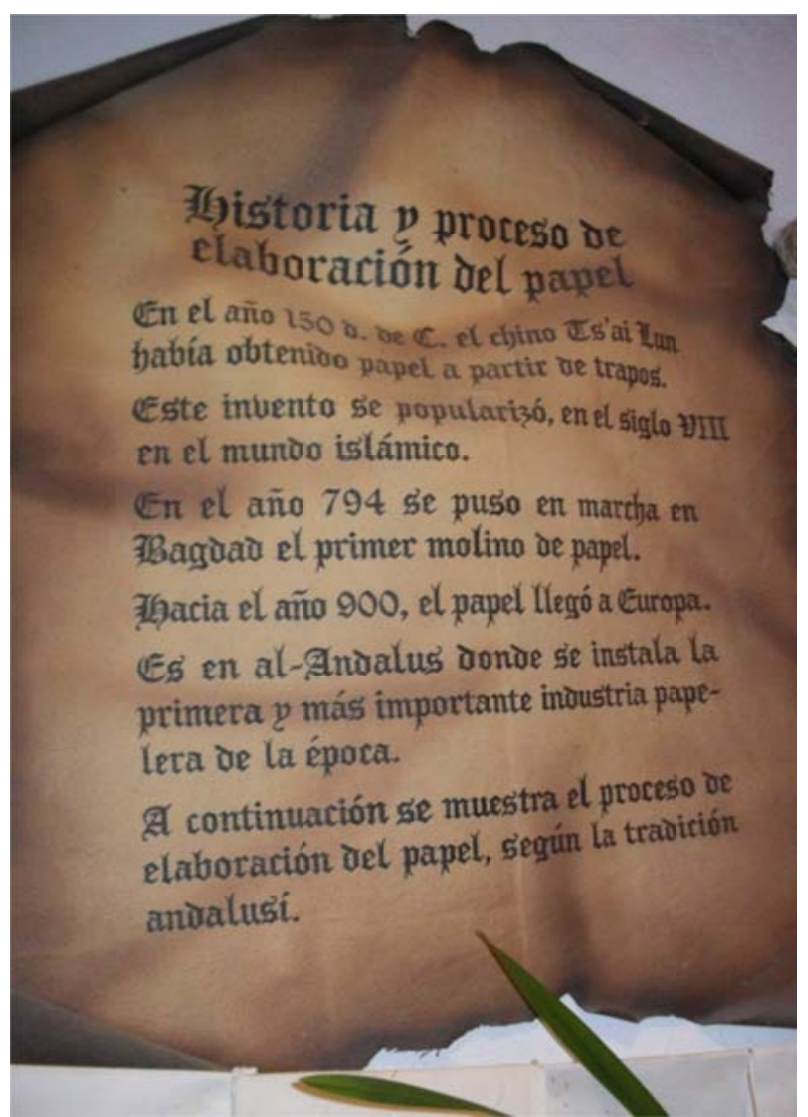

Figure 2. Sample of printed paper at the Museum of Paper in Cordoba, Spain (photographed by Ariadne de Villa).

Medicine was another contribution of Muslim Spain. Cordoba, the capital of Muslim Spain or Al-Andalus, was famous for its scientific advances in medicine. Muslims had stomach operations and cataract surgery. Instruments that were used at that time in the medical field are still used today in the same field.

During the different transitions of the Islamic Caliphate in Muslim Spain and the splendor of the Umayads, when science and theology were united as one source, also giving birth to the Renaissance, women were the primary caretakers of the sick in hospitals. The first female doctors also practiced in the medical field for the first time in Muslim Spain. Nurses were first hired by the Muslim West as well as doctors in the hospitals, where in other geographical areas in the West, this seemed a utopia. In the 15th century, female surgeons were illustrated for the first time in Şerafeddin Sabuncuoğlu's Cerrahiyyetu'l Hanniyye (Imperial Surgery), the first and last mayor encyclopedia of the Islamic World.

\section{Scientific Advances}

Scholars from all over the world came to gain knowledge in all the natural and social sciences, such as medicine, technology for agriculture, astronomy, literature, and Islamic jurisprudence to name a few. This development was important not only for Muslim Spain but also for the whole world. The astrolabe was used to determine the latitude of a ship at sea by measuring the noon altitude of the sun or the meridian altitude of a star of known declination. It was with the help of this astrolabe that Christopher Columbus was able to travel to the American Continent in 1492. Towards the last century of Muslim Spain, Christians had adopted the majority of 
Muslim traditions as well as the scientific discoveries that they had accomplished during more than 800 years in the Iberian Peninsula. Titus Burkhardt (2003) also highlighted the splendor of science during Muslim Spain in his article "Islamic Science": "In Moorish Spain, traditional science had reached such a peak that its influence was felt not only in the Maghrib, but also throughout Latin Christendom. Christian scholars in their writings explicitly referred to their Arab predecessors" (p. 65). Another example stating that the Christiandom in Spain learned from the Moors is a Benedictine monk with the name of Adelhard of Bath, which at the beginning of the 12th century specified the following:

Lest it be thought that one as ignorant as I have fashioned these thoughts for myself, I do declare that they derive from my studies of the Arabs. I do not wish — should anything I say displease certain limited minds - to be the one who displeases them, for I know full well what the truly wise must expect from the common run of men. Therefore, I take care not to speak for myself; I speak only for the Arabs. (Burkhardt, 2003, p. 65)

\section{Conclusion}

It was with the Muslim scientific adoption (like the astrolabe) that later on the Spanish Christians, such as Christopher Columbus and his crew, were able to arrive in the Americas in 1492. In short, even though it is often believed that the inhabitants of Al-Andalus were Arabs, it was in its majority composed of natives of the Iberian Peninsula. This civilization that spanned across eight centuries was a unique model of respect for other languages, cultures, and religions, a model that can serve as an example for our contemporary times.

\section{References}

Álvarez, F. B., \& Pecharromán, J. G. (1998). Historia de España. Sociedad General Española de Librería. (History of Spain. General Spanish Library Association S.A. de Alcobendas: Madrid, P. 48.

Boris, Handal. (2012). La Cultura Hispano Árabe en Latino América, Polis [En línea]. (The Spanish-Arab culture in Latin America. Polis [online]. (pp. 3-5). Retrieved from http://journals.openedition.org/polis/7364

Burkhardt, T. (2003). The essential Titus Burckhardt: Reflections on sacred art, faiths, and civilizations. Retrieved from http://www.worldwisdom.com/public/viewpdf/default.aspx?article-title=Islamic $\% 20$ Science $\% 20$ from $\% 20$ the $\% 20$ Essential $\%$ 20Titus\%20Burckhardt.pdf

De La Guardia, C. (2006). Jews, Christians and Muslims in Spain and Latin America. Spain, Madrid: Middlebury College.

Layna, F. (2006). Don Quijote. Spain: Madrid.

Morrison, J. (2002). The mariner's astrolabe (p. 1). Retrieved from http://www.astrolabes.org/mariner.htm

Olagüe, I. (2004). La revolución Islámica en occidente (The Islamic Revolution in the West) (p. 11). España: Córdoba.

Mashad,Al-Allaf. Muslims and Non-Muslims: Peace Covenant. (p. 120-121) Treaty of Tudmir, Orihuela, Spain, 713CE. Retrieved from

https://books.google.com/books?id=f6eJ_cu5cXAC\&pg=PA121\&lpg=PA121\&dq=In+the+name + of + God, + the + Merciful + ad + Compassionate. + This + is $+\mathrm{a}+$ document $+\% 5$ Bgranted\%5D+by+'Abd+al-'Aziz+ibn+Musá + ibn+Nusair+to+Tudmir, + son + of + Ghabdush, + establishing + a + treaty + of + peace + and + the + promise + and + protection + of + God + and + his + Prophet $+(\operatorname{may}+$ God + ble ss + him+and+grant+him+peace). + We+\%5B'Abd+al-'Aziz\%5D+will+not+set+special+conditions + for + him + o 